\title{
Implications of cloud-computing services in records management in Africa: Achilles heels of the digital era?
}

\begin{tabular}{|c|c|}
\hline \multicolumn{2}{|c|}{$\begin{array}{l}\text { Authors: } \\
\text { Tshepho Mosweu } \\
\text { Lungile Luthuli } \\
\text { Olefhile Mosweu }\end{array}$} \\
\hline \multicolumn{2}{|c|}{$\begin{array}{l}\text { Affiliations: } \\
\text { 'Department of Information } \\
\text { Science, University of } \\
\text { South Africa, Pretoria, } \\
\text { South Africa }\end{array}$} \\
\hline \multicolumn{2}{|c|}{$\begin{array}{l}{ }^{2} \text { Department of Information } \\
\text { Studies, University of } \\
\text { Zululand, Richards Bay, } \\
\text { South Africa }\end{array}$} \\
\hline \multicolumn{2}{|c|}{$\begin{array}{l}\text { Corresponding author: } \\
\text { Olefhile Mosweu, } \\
\text { olfmos@gmail.com }\end{array}$} \\
\hline \multicolumn{2}{|c|}{$\begin{array}{l}\text { Dates: } \\
\text { Received: } 17 \text { Jan. } 2019 \\
\text { Accepted: } 28 \text { Aug. } 2019 \\
\text { Published: } 29 \text { Nov. } 2019\end{array}$} \\
\hline \multicolumn{2}{|c|}{$\begin{array}{l}\text { How to cite this article: } \\
\text { Mosweu, T., Luthuli, L. \& } \\
\text { Mosweu, O., 2019, } \\
\text { 'Implications of cloud- } \\
\text { computing services in records } \\
\text { management in Africa: } \\
\text { Achilles heels of the digital } \\
\text { era?', South African Journal } \\
\text { of Information Management } \\
21(1) \text {, a1069. https://doi. } \\
\text { org/10.4102/sajim. } \\
\text { v21i1.1069 }\end{array}$} \\
\hline \multicolumn{2}{|c|}{$\begin{array}{l}\text { Copyright: } \\
\text { ( 2019. The Authors. } \\
\text { Licensee: AOSIS. This work } \\
\text { is licensed under the } \\
\text { Creative Commons } \\
\text { Attribution License. }\end{array}$} \\
\hline \multicolumn{2}{|c|}{ Read online: } \\
\hline 回管回 & $\begin{array}{l}\text { Scan this QR } \\
\text { code with your } \\
\text { smart phone or } \\
\text { mobile device } \\
\text { to read online. }\end{array}$ \\
\hline
\end{tabular}

Background: Cloud-based services are increasingly used by organisations around the world and Africa is no exception. Literature has revealed that organisations adopt them as they offer efficient and cost-effective services. Notably, Africa is generally at an infant stage in the adoption of cloud-computing services in records management.

Objectives: This article presents and deliberates on the implications of cloud-computing services in archives and records management in Africa and determines whether such services are challenged by the inherent weaknesses faced by Africa in the digital age.

Method: This study adopted a qualitative research approach. It utilised content analysis of the reviewed literature related to cloud computing in records management.

Results: Cloud computing offers good tools for organisations to conduct businesses efficiently and improve their records management practices. However, issues related to records storage, jurisdiction, privacy, security and the digital divide, to mention a few, are a challenge that need to be surmounted if Africa is to benefit fully from cloud-based records management services.

Conclusion: Although cloud-computing services in records management promise huge benefits for Africa, the continent is not ready to fully embrace such technologies and benefit from them. Actually, cloud-based records management services are an Achilles heel for Africa.

Keywords: Africa; cloud-computing; ICTs; records management; digital records.

\section{Introduction}

The National Institute of Standards and Technology (NIST) (2011) of the United States' Department of Commerce defines cloud computing as:

\footnotetext{
... a model for enabling convenient, on-demand network access to a shared pool of configurable computing resources (e.g., networks, servers, storage, applications, and services) that can be rapidly provisioned and released with minimal management effort or cloud provider interaction. (p. 3)
}

Kabata (2012) defines it as a form of distributed storage involving shared hardware or several virtual machines running on a physical machine. ARMA (2010) indicates that cloud computing is still an evolving technology, so it should not be a surprise that it is defined differently by different users because it means different things to different people. According to the InterPARES Trust (2016), the use of cloud-computing services by businesses has grown exponentially over the years. For example, Google claims that 5 million businesses subscribed to Google apps. A study in 2010 by the Poneman Institute found that $56 \%$ of information technology (IT) practitioners surveyed worked for organisations that were actively utilising the cloud in some capacity. NIST (2011) avers that cloud-computing services can be executed through a variety of architectures under different services and deployment models and these can be harmonised with other technologies and software design approaches.

Gillwald and Moyo (2012) argue that cloud computing in Africa is still at an infant stage because global US-based companies have dominated the cloud-computing market. Even though it is clear that cloud computing offers good tools for organisations to conduct their businesses efficiently and improve records management, African countries still experience some hiccups that have prevented them from fully reaping the rewards brought by cloud-computing services. According to Asogwa (2012), issues of low gross national products (GNPs), corruption and unstable political systems affect proper records management implementation in Africa. Nwabuonu and Nwachukwu (2014) argue that although the problems of IT in West African 
sub-region were caused by the cost of IT infrastructure, such as computer, software installation and maintenance, low Internet penetration, cyber threat and a host of other challenges, they believe that if cloud computing is adopted, some of these problems would be eliminated or minimised. Governments in most of African countries have been playing a significant role in the cloud services market by endorsing public cloud services to deliver their e-government services (Gillwald \& Moyo 2012). A similar study was undertaken in Uganda where commercial banks adopted cloud-computing technology and managed to increase capacity to store data and manage it virtually, thus benefitting from cloudcomputing technology (Mugyenyi 2018). In addition, cloudcomputing technology ensures that data, records and information are always available as they are backed up on a number of computers which diminishes the possibility of data and application loss.

\section{Study objectives}

The study utilised the qualitative research approach and collected data from the literature. Content analysis was used for data analysis. In an attempt to answer the question whether the implications of cloud-computing services in records management in African countries are an Achilles heel of the digital era, the study formulated the following objectives:

- To investigate the benefits of cloud computing in records management in Africa.

- To determine the challenges associated with cloud computing in general, and records management in particular in the African context.

- To recommend possible measures that can be instituted to deal with risks and challenges of records management cloud computing in Africa.

\section{Research methodology}

This study adopted surveyed literature in order to address the research objectives using content analysis. Other studies such as one by Keakopa (2010), which provided an overview of archival and records management developments in the Eastern and Southern Africa Regional Branch of the International Council on Archives (ESARBICA) member countries, have also been based on desktop research. This study also employed content analysis as part of the endeavour to address the research objectives. Similar studies by Ngoepe and Makhubela (2015) and Ngoepe and Saurombe (2016), which investigated the relationship between records management and the travesty of justice in South Africa, and provisions for managing and preserving records created in networked environments in the archival legislative frameworks of selected member states of the Southern African Development Community (SADC), also utilised content analysis. Content analysis from empirical studies, Internet resources and policy documents was performed to address research objectives. To contextualise the study, an insight into cloud-computing models and cloud-computing service types is offered. This is over and above the context set out in the introduction to this article.

\section{Cloud-computing models}

There are four types of cloud-computing models: public, community, private and hybrid clouds (Charlesworth, Beagrie \& Miller 2014; InterPARES 2014; McKemmish 2013). Cloud-computing clients need to appreciate potential security benefits and threats connected with cloud computing, and establish realistic expectations with their cloud service providers. Consideration includes different services and categories set by infrastructure as a service (IaaS), platform as a service (PaaS) and software as a service (SaaS), because each model carries diverse security requirements and responsibilities (Cloud Standards Customer Council 2017).

\section{Public cloud}

It provides the cloud infrastructure for open use. It may be owned, managed and operated by a business, academic or government organisation, or their mixture. It exists on the premises of the cloud provider (Government of South Australia 2015). This is the most common and widely recognised cloud-computing deployment model. It works through widely distributed data centres around the globe and accessible over public networks to anyone able to pay for service (Charlesworth et al. 2014). It is a form of multiple tenancies whereby client organisations share the use of expensive hardware for the offered menu of configurations. Customers select from the available set.

\section{Community cloud}

Community cloud deployment cloud service where specified groups of clients share the same cloud service (McClelland et al. 2014). This deployment allows client organisations to have security of knowledge of fellow users using the same cloud infrastructure, over and above benefitting from the use of the service. According to Hon, Hörnle and Millard (2012), in community cloud computing, the infrastructure is owned by or operated for, and shared amongst, a specific limited set of users with common interests. For example, a US government client organisation can operate a community cloud jointly with a UK local government department.

\section{Private cloud}

The term private cloud denotes customers who access the infrastructure. The client organisation that has purchased the service has its information deposited in the infrastructure. The information is physically isolated from that of other clients (Low 2012). The use of private cloud-computing deployment leans towards reduced operational costs and is cost-effective when used by organisations that already have noteworthy investment in data centre space, equipment and personnel (Charlesworth et al. 2014). InterPARES (2014) notes that the private cloud, comparatively, especially if it is owned and maintained by the client itself, is generally costlier than the public model, but can potentially offer more enhanced assurances of security and privacy. 


\section{Hybrid cloud}

The last kind of cloud deployment model is known as the hybrid cloud. The set-up is completed by different types of cloud deployment models (Government of South Australia 2015; Zissis \& Lekkas 2012). The infrastructure is deployed in such a manner that some would be in the shared space of the public model and some would be the secluded infrastructure of the private model (McClelland et al. 2014). However, the infrastructure remains unique entities but they are bound together by standardised or proprietary technology that enables data and application portability (Government of South Australia 2015). Hybrid cloud computing is more appropriate where there is a need to separate client organisation complex and non-complex data (McClelland et al. 2014; Wang, Rashid \& Chuang 2011). Figure 1 is a graphic depiction of the four different types of cloud-computing models.

\section{Cloud-computing service types}

The literature shows that there are four types of cloudcomputing services available to users, which are IaaS, SaaS, PaaS and, less commonly, data as a service (DaaS) (ARMA 2010; Government of South Australia 2015; Hsu 2012; InterPARES 2014; ITA 2016; Low 2012; McKemmish 2013). Data as a service is the least common service type of cloudcomputing services.

\section{Infrastructure as a service (laaS)}

According to the Government of South Australia (2015), IaaS refers to the online delivery of virtual infrastructure constituents such as servers, storage and network access. Low (2012) describes it as the provision of access to hardware. The client rents rather than procures the IT infrastructure on an as-needed basis, allowing it to upsurge infrastructure capability easily and rapidly when necessary (InterPARES 2016). It allows for depiction of automation through different resources such as the infrastructure needed to be deployed and run an organisation's own software applications (Government of South Australia 2015). The rented infrastructure is accessible to the client remotely through the Internet (InterPARES 2016).

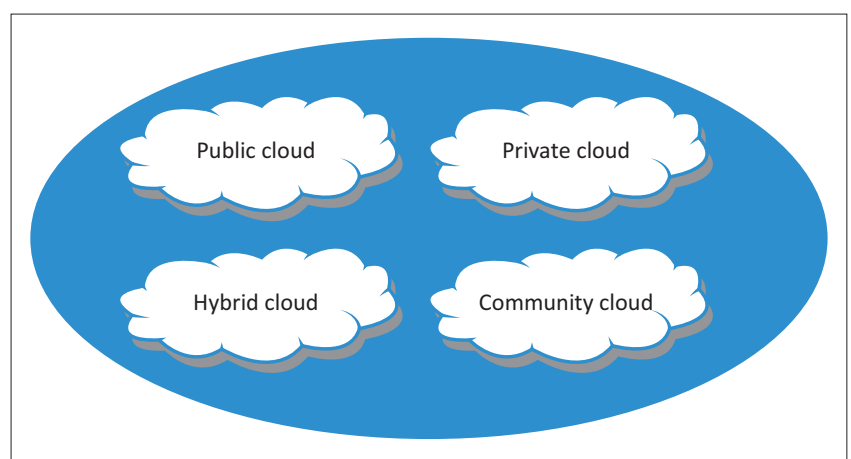

Source: Somepalle, S., 2015, 3 service and 4 deployment models of cloud computing, viewed 06 May 2018, from https://www.linkedin.com/pulse/3-service-4-deploymentmodels-cloud-computing-sankar-somepalle

FIGURE 1: Graphic illustration of the four different types of cloud-computing models.

\section{Software as a service}

Software means a service which allows the client to access remotely software that is hosted on infrastructure owned and maintained by the service provider (Low 2012). Its advantage is that the client organisation is able to utilise software that would have been expensive had it been purchased, installed, maintained and updated (InterPARES 2014; McClelland et al. 2014).

\section{Platform as a service}

Platform as a service refers to the online delivery of a custom application deployment environments in which applications can be built and run on service provider systems (Government of South Australia 2015). This is performed by building custom web applications without installing any tools on an organisation's computers and then deploying those applications without the necessity for specialised system administration skills. The client organisation can build its own software using the platform provided (McClelland et al. 2014). Figure 2 depicts the three most common types of cloud-computing services.

\section{Data as a service}

Data as a service is the least common amongst the three cloud-computing service types. It is normally embedded within a SaaS, PaaS or IaaS solution and gives (often spatial) data within applications that support data discovery, access, manipulation and use, and often provides spatial data applications that support more specialised data discovery, access, manipulation and use (Low 2012). Data as a service can be viewed as a cousin of the SaaS family. According to Rajesh, Swapna and Reddy (2012), it is founded on the conception that data (viewed as a product) can be provided on demand to the user without regard to the location of the service provider and consumer. The advent of serviceorientated architecture (SOA) has rendered irrelevant an actual platform on which the data reside, enabling the advance of DaaS emergence.

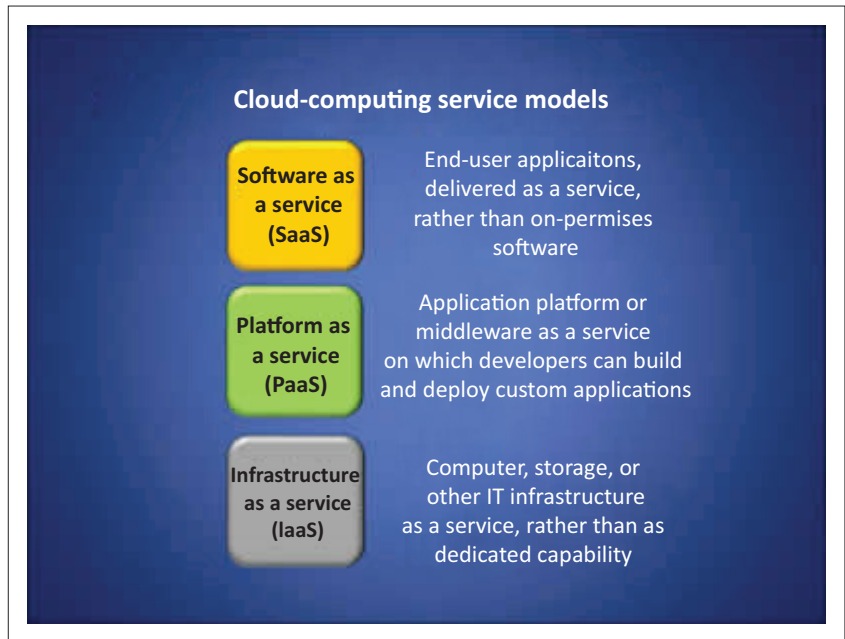

Source: Somepalle, S., 2015, 3 service and 4 deployment models of cloud computing, viewed 06 May 2018, from https://www.linkedin.com/pulse/3-service-4-deploymentmodels-cloud-computing-sankar-somepalle

FIGURE 2: The three most common cloud-computing service models. 


\section{Cloud computing in records management}

The 1990s experienced an information and communication technology (ICT) revolution, especially the Internet and the World Wide Web (Wamukoya \& Mutula 2005). Governments, including those in Africa, adopted these ICTs as part of wider public sector reforms (Keakopa 2008; Mnjama \& Wamukoya 2007; Mosweu 2016; Wamukoya \& Mutula 2005). The use of ICTs results in the generation of electronic records (Mosweu 2012; Wamukoya \& Mutula 2005). The adoption of ICTs in public service delivery has now partly experienced a shift towards cloud computing for records management (Haskew et al. 2015; Kabata 2012; Palmer 2012). This is because it offers attractive benefits for records management including significant cost savings, enhanced reliability and access to records remotely, flexibility, scalability, improved business processes, freedom from the responsibilities of server ownership, enhanced protection against data loss, increased collaboration and business continuity or disaster recovery for records management (Bassett 2015; Carroll, Van der Merwe \& Kotzé 2011; Kabata 2012; McKemmish 2013).

\section{Benefits of cloud-computing services in records management}

Evidence from the literature indicates that cloud computing has a number of benefits for businesses of client organisations. According to a number of authors, these benefits are significant and include cost savings, enhanced reliability and access to records remotely, flexibility, scalability, improved business processes, freedom from the responsibilities of server ownership, enhanced protection against data loss, increased collaboration and business continuity or disaster recovery (Bassett 2015; Carroll et al. 2011; Kabata 2012; McKemmish 2013). A detailed argument on the positive outcomes of cloud computing in records management follows below.

\section{Cost savings}

Less equipment is required by organisations, lower than in-house solutions and less use of energy. Geier (2010) observes that offline cloud storage does not carry hefty acquisition costs associated with on-premises storage requirements. Offpremises storage has lower monthly operating costs as a client organisation does not have to have personnel for a data centre or pay for electrical and additional cooling costs related to the equipment. In addition, costs including equipment failure are borne by the cloud storage provider (Geier 2010). This reduces the need to store additional hardware as backup equipment or carry on additional service contracts.

\section{Enhanced reliability and access to records remotely}

With cloud computing, there is ease of access to services and applications as compared to the more traditional organisational model of hardware or software purchase, installations and deployment. The location of services and applications in the cloud enables user access remotely as long as the Internet is available (InterPARES/ ICA 2012). This makes cloud computing more efficient. For example, the cloud environment can afford new technological and/or economic solutions for users which were not feasible without cloud computing and the efficiency provided by the cloud can allow for the reallocation of IT services to other responsibilities (InterPARES/ICA 2012).

\section{Flexibility}

Less is spent on hardware and data are easily accessible without having to carry a lot of equipment. According to Blaisdell (2012), cloud computing enables workers to be more flexible while away from or at work. Employees can access files using web-enabled devices such as smartphones, laptops and notebooks. The ability to share documents and other files concurrently over the Internet can also help support both internal and external cooperation. Many employers are now implementing 'bring your own device (BYOD)' policies. In this way, cloud computing enables the use of mobile technology.

\section{Scalability}

Cloud computing allows organisations to upscale or downscale IT requirements easily when needed. Cloud computing allows for fast and easy distribution of resources in an observed environment where overloading is never a concern as long as the system is managed correctly. According to Geier (2010), storage in the cloud is limitless to an organisation. For example, when engaging a cloud-based records management service provider, additional hardware and installation into a local data centre are not required. This is because the trustworthiness and availability of the medium is built into the architecture, thereby not necessitating additional planning.

\section{Improved business processes}

Cloud computing gives a variety of prospects that help the organisations to advance their business and use technology more proficiently making it the most popular and promising technology (Thomas 2009). The world business fraternity has become competitive to such an extent that an organisation cannot survive using the traditional ways when conducting business. This is because the competitive business environment requires organisations to respond quickly to business demands. As a result, cloud computing serves as an enhanced technology that has become vital in running a business. Thomas (2009) opines that cloud computing acts as an excellent technological tool as it offers a wide range of solutions and advantages to business that permit the users and consumers to integrate and combine a variety of services to increase creativity and productivity. 


\section{Enhanced protection against data loss}

Data loss prevention (DLP) tools can help control migration of data to the cloud and enhance data security in the cloud. Crashing of servers and computers may lead to loss of valuable information. Therefore, this emphasises the issue of customers and organisations losing valuable data stored in the cloud. Some of the issues include the possibility of probing and attacks of various kinds. The use of viruses, worms and cyber-terrorism remains a significant factor leading to data loss. Therefore, DLP is the solution to cloud computing and can arrest it as an Achilles heel of the digital age in cloudbased records management. According to the Solicitors Regulation Authority (2013), the clever use of cloud-based systems can decrease threats of data loss from occurring.

\section{Increased collaboration}

In a study that asked respondents about their reasons for adopting cloud computing, 54\% gave increased collaboration as a reason for the cloud-computing adoption (Duranti 2013). Increased collaboration implies a transformation of work processes. Duranti (2013) avers that:

... for records management the increasing use of cloud computing for work suggests that more and more records will be generated directly in the cloud, whose underlying infrastructure most users do not have ownership. (p. 13)

For example, with DocuSign, a third-party cloud-based solution that permits organisations to enclose digital signatures from partners' signing authorities, it is possible for end users to sign uploaded templates and store them in the cloud. Later, records management professionals can declare such signed documents as records.

\section{Business continuity or disaster recovery}

The National Archives of Australia (2018) defines business continuity as a planned activity undertaken by an organisation to ensure that critical business information remains available. Records as organisational assets need to be available to transact business. Business continuity that includes records management is thus a necessity. The Australian Capital Territory (2008) underscores the critical need to safeguard records and records-related business information systems from being affected by risks of disruption from potential disasters. Business continuity planning for records management incorporates a business risk impact assessment for records and a business continuity plan for records. Records entrusted to the cloud also need to encompass a business continuity plan. The Cloud Security Alliance (2012) indicates that business continuity and disaster recovery are requirements when using cloud services to provide the IaaSor PaaSor SaaS for production environments. These ensure that services are backed up and/ or replicated to another site. That is performed through replicating business continuity and disaster recovery capabilities to another data centre either by default or as an extra service, or through a combination of the two (Cloud Security Alliance 2012). Some platforms replicate all data to an additional data centre by default, but not the whole system in a live state. Cloud-based records management may include commercial continuity and disaster recovery plans for records management.

\section{Cloud computing in Africa}

Cloud computing is fast and growing technology in the African region. Internet penetration across the continent has made it possible for cloud computing to thrive especially where conditions for its adoption are in place. Statistics on Internet penetration in Africa show some growth, including Facebook subscribers (Miniwatts Marketing Group 2019). Table 1 shows Internet penetration across the African continent for the year 2019, as at 31 March 2019.

Basically, the Internet facilitates the use and the implementation of cloud-computing services. In Nigeria, small- and mediumsized enterprises (SMEs) adopted cloud computing because of its potential to support economic growth (Abubakar, Bass \& Allison 2014). Spanning a number of sectors such as finance, ICT and manufacturing in a study that included 10 SMEs, the findings revealed that in opposition to the available literature on cloud computing in developed countries, the SMEs were less concerned about challenges such as security, privacy and data. They were somewhat optimistic and concentrated on the potential opportunities brought by cloud computing (Abubakar et al. 2014).

The adoption of cloud computing by companies in Ethiopia is somewhat different from that in Nigeria in that the adopters are more worried with challenges such as security, privacy and trust issues as well as government telecommunications infrastructure policies and acquiring cloud technology skills (Seifu et al. 2017). The companies were from sectors such as finance, ICT training, research, construction and manufacturing. One notable weakness in the adoption of cloud-computing services was that the enterprises were yet to adopt cloud computing as an IT provisioning method and they lacked awareness of the advantages and disadvantages of adopting the cloud (Seifu et al. 2017).

In Kenya, although organisations have adopted cloudcomputing services, ResearchICTafrica.net (2017) reports that the government has offered little support for the cloud industry. This is despite government being in a position to kindle the industry by providing backing policies and pledging to cloud services. Notably, the ICT authority responsible for ICT services has issued a cloud service standard that is unfortunately not being enforced. In addition, the procurement laws are outdated and still reflect the traditional methods of procuring ICT hardware and services (ResearchICTafrica.net 2017).

In general terms, the adoption of cloud-computing services is on an upward trend. A positive network infrastructure development with constantly improving international connectivity is in place (International Telecommunications Union [ITU] 2012). International cables installed on each side of the African continent have enabled improved connectivity 
TABLE 1: Internet users Statistics for Africa: Africa 2019 populace and WebCrawlers user statistics.

\begin{tabular}{|c|c|c|c|c|c|c|}
\hline Africa & $\begin{array}{l}\text { Population } \\
\text { (2019 Est.) }\end{array}$ & $\begin{array}{l}\text { Internet Users: } \\
\text { 31 December } 2000\end{array}$ & $\begin{array}{l}\text { WebCrawler's ('Internet') } \\
\text { Users } 31 \text { March } 2019\end{array}$ & $\begin{array}{c}\text { Penetration } \\
\text { (\% Population) }\end{array}$ & $\begin{array}{c}\text { Internet Growth } \\
\% \text { 2000-2019 }\end{array}$ & $\begin{array}{l}\text { Facebook subscribers } \\
31 \text { December } 2017\end{array}$ \\
\hline Algeria & 42679018 & 50000 & 21000000 & 49.2 & 41.90 & 19000000 \\
\hline Angola & 31787566 & 30000 & 7078067 & 22.3 & 23.49 & 27400000 \\
\hline Benin & 11801595 & 15000 & 3801758 & 32.2 & 25.25 & 920000 \\
\hline Botswana & 2374636 & 15000 & 923528 & 38.9 & 6.06 & 830000 \\
\hline Burkina Faso & 20321560 & 10000 & 3704265 & 18.2 & 36.94 & 840000 \\
\hline Burundi & 11575964 & 3000 & 617116 & 5.3 & 20.47 & 450000 \\
\hline Cabo Verde & 560349 & 8000 & 265972 & 47.5 & 3.23 & 240000 \\
\hline Cameroon & 25312993 & 20000 & 6128422 & 24.2 & 30.54 & 2700000 \\
\hline Central African Rep. & 4825711 & 1500 & 256432 & 5.3 & 17.00 & 96000 \\
\hline Chad & 15814345 & 1000 & 768274 & 4.9 & 76.73 & 260000 \\
\hline Comoros & 850910 & 1500 & 130578 & 15.3 & 8.61 & 120000 \\
\hline Congo & 5542197 & 500 & 650000 & 11.7 & 129.90 & 600000 \\
\hline Congo, Dem. Rep. & 86727573 & 500 & 5137271 & 5.9 & 1027.35 & 2100000 \\
\hline Côte d'Ivoire & 25531083 & 40000 & 6318355 & 25.6 & 16.25 & 3800000 \\
\hline Djibouti & 985690 & 1400 & 180000 & 18.3 & 12.76 & 180000 \\
\hline Egypt & 101168745 & 450000 & 49231493 & 48.7 & 10.84 & 35000000 \\
\hline Equatorial Guinea & 1360104 & 500 & 312704 & 23.0 & 62.44 & 67000 \\
\hline Eritrea & 5309659 & 5000 & 71000 & 1.3 & 1.32 & 63000 \\
\hline Eswatini & 1415414 & 10000 & 446051 & 31.5 & 4.36 & 170000 \\
\hline Ethiopia & 110135635 & 10000 & 16437811 & 14.9 & 164.28 & 4500000 \\
\hline Gabon & 2109099 & 15000 & 985492 & 46.7 & 6.47 & 620000 \\
\hline Gambia & 2228075 & 4000 & 392277 & 17.6 & 9.71 & 310000 \\
\hline Ghana & 30096970 & 30000 & 10110000 & 33.6 & 33.60 & 4900000 \\
\hline Guinea & 13398180 & 8000 & 1602485 & 12.0 & 19.93 & 1500000 \\
\hline Guinea-Bissau & 1953723 & 1500 & 120000 & 6.1 & 7.90 & 110000 \\
\hline Kenya & 52214791 & 200000 & 43329434 & 83.0 & 21.56 & 7000000 \\
\hline Lesotho & 2292682 & 4000 & 627860 & 27.4 & 15.60 & 310000 \\
\hline Liberia & 4977720 & 500 & 4028418 & 80.9 & 805.58 & 4028418 \\
\hline Libya & 6569864 & 10000 & 3800000 & 57.8 & 37.90 & 3500000 \\
\hline Madagascar & 26969642 & 30000 & 1900000 & 7.0 & 6.23 & 1700000 \\
\hline Malawi & 19718743 & 15000 & 1828503 & 9.3 & 12.09 & 720000 \\
\hline Mali & 19689140 & 18800 & 12480176 & 63.4 & 66.28 & 1500000 \\
\hline Mauritania & 4661149 & 5000 & 810000 & 17.4 & 16.10 & 770000 \\
\hline Mauritius & 1271368 & 87000 & 803896 & 63.2 & 824.00 & 700000 \\
\hline Mayotte (FR) & 266380 & $\mathrm{n} / \mathrm{a}$ & 107940 & 40.5 & $\mathrm{n} / \mathrm{a}$ & 71000 \\
\hline Morocco & 36635156 & 100000 & 22567154 & 61.6 & 22.47 & 15000000 \\
\hline Mozambique & 31408823 & 30000 & 5279135 & 16.8 & 17.50 & 1800000 \\
\hline Namibia & 2641996 & 30000 & 797027 & 30.2 & 2.56 & 570000 \\
\hline Niger & 23176691 & 5000 & 951548 & 4.1 & 18.93 & 440000 \\
\hline Nigeria & 200962417 & 200000 & 111632516 & 55.5 & 55.72 & 17000000 \\
\hline Réunion (FR) & 889918 & 130000 & 480000 & 53.9 & 269.00 & 420000 \\
\hline Rwanda & 12794412 & 5000 & 3724678 & 29.1 & 74.39 & 490000 \\
\hline Saint Helena (UK) & 4096 & $\mathrm{n} / \mathrm{a}$ & 2200 & 53.7 & $\mathrm{n} / \mathrm{a}$ & 1700 \\
\hline Sao Tome \& Principe & 213379 & 6500 & 57875 & 27.1 & 790.00 & 52000 \\
\hline Senegal & 16743859 & 40000 & 9749527 & 58.2 & 24.27 & 2900000 \\
\hline Seychelles & 95702 & 6000 & 67119 & 70.1 & 1.02 & 61000 \\
\hline Sierra Leone & 7883123 & 5000 & 902462 & 11.4 & 17.95 & 450000 \\
\hline Somalia & 15636171 & 200000 & 1200000 & 7.7 & 599.90 & 1100000 \\
\hline South Africa & 58065097 & 2400000 & 31185634 & 53.7 & 1.20 & 16000000 \\
\hline South Sudan & 13263184 & $\mathrm{n} / \mathrm{a}$ & 2229963 & 16.8 & $\mathrm{n} / \mathrm{a}$ & 180000 \\
\hline Sudan & 42514094 & 30000 & 11816570 & 27.8 & 39.29 & 2600000 \\
\hline Tanzania & 60913557 & 115000 & 23000000 & 37.8 & 19.90 & 6100000 \\
\hline Togo & 8186384 & 100000 & 899956 & 11.0 & 800.00 & 560000 \\
\hline Tunisia & 11783168 & 100000 & 7898534 & 67.0 & 7.80 & 6400000 \\
\hline Uganda & 45711874 & 40000 & 19000000 & 41.6 & 47.40 & 2600000 \\
\hline Western Sahara & 582478 & $\mathrm{n} / \mathrm{a}$ & 28000 & 4.8 & $\mathrm{n} / \mathrm{a}$ & 24000 \\
\hline Zambia & 18137369 & 20000 & 7248773 & 40.0 & 36.14 & 1600000 \\
\hline Zimbabwe & 17297495 & 50000 & 6796314 & 39.3 & 13.49 & 880000 \\
\hline Total Africa & 1320038716 & 4514400 & 492762185 & 37.3 & 10.82 & 204304118 \\
\hline Rest of world & 6396184493 & $82.9 \%$ & 3891048157 & 60.8 & 88.80 & 1942054452 \\
\hline World total & 7716223209 & $100.0 \%$ & 4383810342 & 56.8 & 100.0 & 2146358570 \\
\hline
\end{tabular}

Source: Miniwatts Marketing Group, 2019, 'Internet users statistics for Africa', viewed 09 July 2019, from https://www.internetworldstats.com/stats1.htm

Note: (1) Africa WebCrawler's or 'Internet' Statistics were updated on 18 May 2019. (2) Africa Facebook subscribers are estimated on 31 December 2017. (3) Africa population numbers are mid-year 2019 estimates, based on data from the United Nations Population Division. (4) For definitions, navigation help and methodology, see the site surfing guide. (5) Africa Internet usage information comes from, amongst others, data published by WWW, ITU, Facebook and other trustworthy sources. (6) For Internet growth comparison purposes, baseline Internet usage data for the year 2000 are also displayed. (7) Data from this table may be cited, giving the due credit to Internet World Stats and establishing a link back to http://www.internetworldstats.com Copyright 2019, $\mathbb{C}$
Miniwatts Marketing Group. All rights reserved worldwide. n/a, not applicable; Dem. Rep., Democratic Republic; FR, France; UK, United Kingdom. 
and an increase in telephone and Internet traffic and the emergence of an ever-increasing number of data centres has been seen, something that can be managed only virtually, via the web. For example, a consultancy firm known as Balancing Act published a report in 2011 which shows a number of data centres in the continent, including 15 in South Africa, 11 in Egypt, Ghana and Nigeria, 10 in Kenya and one in Tunisia (ITU 2012)

Adane (2018) sees that the state of cloud computing in Africa requires the adoption of specific strategies that will meet their specific needs if cloud computing is to play a sturdier role in supporting their needs for its use. Cloud computing offers benefits to records management because it is costeffective and enables multiple storage systems, which can be accessed anywhere or anytime (Bassett 2015). Legal issues still need to be dealt with when venturing into cloud computing and keeping both parties happy, that is, both the clientele and the organisation at large. The next section presents the challenges of cloud-computing services for the management of records.

\section{Challenges of cloud-computing services in records management}

Studies undertaken on the implementation of systems to manage trustworthy digital records in the public sectors of Botswana, Kenya and Zimbabwe revealed that emergent technologies such as cloud computing are yet to be made part of records management (InterPARES 2018a, 2018b, 2018c). Most of the respondents in these studies indicated that they have not implemented cloud computing in their institutions and those who responded opined that they did not know whether it included records management (InterPARES 2018a, $2018 b, 2018 c)$. The following barriers for the adoption of cloud computing are, in fact, the challenges experienced with cloud-computing services.

\section{Digital divide}

Mutula (2008) puts digital divide as one of the greatest challenges for developing countries, especially the African ones. According to Spectar (2000), amongst others, the term digital divide refers to the inequitable access to ICTs, which includes the Internet. Cloud-computing service applications rely on access to the Internet. According to Wamuyu (2017), one of the biggest challenges to cloud computing is access to the Internet in Africa. Access to ICTs including the Internet is costly in South Africa, Botswana and Namibia (Keakopa 2008). Much as this is described as a challenge, Internet penetration in Africa has seen growth over the years as shown by Internet usage statistics as at 2017 (Miniwatts Marketing Group 2019). Despite this positive development, the development of international data transmission links between Africa and the rest of the world is so costly that it is not sustainable to realise transferring 'African data' to and from cloud-computing resources located outside Africa (whether for storage or for data consultation purposes). Comparatively, it is cheaper to build data storage centres in
Africa than to pay for accessing centres situated tens of thousands of kilometres away from the continent (ITU 2012).

Cloud-computing services are generally web-based and lack of Internet access negatively affects their adoption. Related to this is the issue of unreliable power supply that is problematic in West African countries, including Nigeria. The unreliable supply of electricity impedes the information infrastructure capable of supporting e-government initiatives, some of which are deploying electronic records systems (International Records Management Trust [IRMT] 2004). In general terms, the digital divide is slowly being closed as Africa is leapfrogging ICT development, which is also fuelled by mobile telephony and broadband (Mensah 2019), although the reality is that some African countries are digital oases with their European counterparts, while some are still digital deserts.

\section{Unreliable nature of cloud services}

Kabata (2012) and Dvorak (2011) aver that one of the main concerns common with cloud-computing services relates to its unreliability. Because of the nature of business, cloudcomputing services have become targets for hackers or malicious insiders. Dvorak (2011) and Kabata (2012) note that big cloud-computing service providers such as Amazon, Google (which had problems and lost email accounts), Google Apps, Sonny (which struggled with its online gaming system) and even Microsoft experienced setbacks. This call for advanced training of records managers in Africa equips them with the know-how for coping with these challenges. Inadequate skilled labour in managing digital records has been found to be a challenge in Africa (Ngulube 2004).

\section{Security of data is compromised in the cloud}

Security of data stored in the cloud is questionable. The key concern is data privacy whereby, in most cases, organisations do not have control of or know where cloud providers store their data (Lewis 2012). Dvorak (2011) points out that using the cloud is risky because of users' over-reliance and failure to adequately back up everything and failure to have a backup strategy. McKemmish (2013) argues that gains and benefits associated with cloud computing need to be weighed against risks involved such as risks to privacy, security and records management. Nwabuonu and Nwachukwu (2014) posit that the fear of loss of data by IT users has been reduced as data stored in the cloud can still be accessed, no matter what happens to a machine.

\section{Non-compliance with legal requirements}

The management of records in the cloud is subject to legal and regulatory requirements. However, in practice, cloud vendors do not often specify where a client organisation's information is physically stored, including their distributed server environment, which can result in client data being stored in more than one jurisdiction (Kabata 2012). Yimam and Fernandez (2016) opine that the very nature of cloudcomputing technology makes the issue of compliance a shared 
responsibility for client organisations, cloud service providers, service brokers and auditors. There are repercussions for noncompliance with legal and regulatory requirements (NIST 2011). In the United States, Canada and the European Union, tenants or client organisations are subject to numerous regulatory requirements (Winkler 2012). Non-compliance with legal requirements is also a challenge in Africa, where cloud-computing services are hampered by inadequate and outdated legislation in the archives and records management field, as found by different scholars (Asogwa 2012; Mosweu 2012; Ngoepe \& Saurombe 2016). Lewis (2012) posits that because of the tendency of cloud vendors to locate server farms and data centres where it is cheaper to operate them, some cloud-computing users have concerns about jurisdiction, data protection, fair information practices and international data transfer. Gillwald and Moyo (2012) posit that in most cases in Africa, legislation addressing data protection, security and privacy is absent. For example, although cloud computing falls within the wider ICT ecosystem, there was no mention of issues that relate to cloud computing in legislation in Ethiopia, Ghana, Kenya, Nigeria and Tunisia.

\section{Lack of open standards and interoperability}

In cloud computing, a lack of open standards and interoperability is an issue to always bear in mind (Kabata 2012; Venkatramam 2012). This makes it, amongst others, difficult to move workloads between private clouds and public clouds. Hindrance of Cloud adoption has been attributed to this hiccup. The use of this tactic enables the use of open standards through interoperability as the standardisation for the clouds. However, this term refers to the portability of cloud computing, whereas the community sees the lack of cloud interoperability as an obstacle to cloudcomputing adoption because organisations fear 'vendor lockin'. Vendor lock-in refers to the fear of being bound to a vendor, preventing movement from one vendor to another because of increases in service fees. However, risks are identified which include reduced negotiation power in reaction to price increases and service discontinuation because the provider goes out of business. This, however, proves the need for the implementation of standards that will be based specifically on the use of cloud computing in records management as a whole. The State of Kentucky (2012) advises that as information stored in many information systems must be maintained and accessible even after the system has become obsolete, organisations must contemplate an exit strategy any time the organisation considers the deployment of new IT, including cloud-computing services. Before actual usage of the service, it is imperative to ensure that information is accessible and not contained within a proprietary system that is expensive.

\section{Summary on the implications of cloud-computing services in records management in Africa}

Although cloud computing offers opportunities for improving delivery of services (IBM 2010) for developing countries such as those in Africa, it is an Achilles heel and does not avail full benefits as intended. A number of factors such as bandwidth, licensing issues, power supply, digital divide, capability building, quality of service, ICT infrastructure needs and security and privacy concerns (InterPARES/ICA 2012; ITU 2012; Mujinga \& Chipangura 2011; Oyeleye, Fagbola \& Daramola 2014; Sabi 2014) are of concern. These are the very challenges already identified as challenges faced in the use of cloud-based records management systems. A recap of these challenges, which in the context of this study are an Achilles heel, shows that low bandwidth hinders the effective use of deployed electronic records management systems.

Power supply is another hindrance to sustained use of electronic-based records management systems. Electricity is expensive in Africa and puts rural communities at a bigger disadvantage than their urban counterparts. The poorly developed electrical distribution network contributes to the digital gaps, resulting in an inability to support ICT infrastructure (Bagula et al. 2011). The authors indicate that in Malawi, approximately $8 \%$ of the population have access to electricity, with less than $2 \%$ from rural communities. Lack of a constant supply of electricity is also cited as a factor that hinders the successful implementation and adoption of electronic health records (EHR) systems in sub-Saharan Africa (Odekunle, Odenkunle \& Shankar 2017). Many hospitals in the region do not have reliable power supply and use alternative power supply such as generators for their operations. For example, in Nigerian Tertiary Hospital, an EHR was not used for months because of constant power outage (Awokola et al. 2012).

The digital divide also hampers cloud-based records management solutions. According to Lesame (2005), the term digital divide refers to 'the gap between the access of individuals, households, organisations, countries and regions at different socioeconomic levels of ICTs and Internet usage'. Cloud-based records management relies on Internet availability for its success. The unreliable supply of electricity impedes the information infrastructure capable of supporting e-government initiatives some of which deploy electronic records systems (IRMT 2004).

Cloud-based records management needs a strong ICT infrastructure for its operations. According to Keakopa (2008), ICT infrastructure availability is still problematic in Africa. Kanyengo (2009) has also noted that ICT infrastructure in most African countries is concentrated more in urban centres than rural areas. It is through universities' government ministries and departments, hotels and lodges that access to the Internet is provided. This then means that the use of ICTs is limited in overall terms. In such a scenario, the use of the cloud for records management cannot thrive as it depends on the Internet to operate.

Moatlhodi and Kalusopa (2016) aver that lack of capacity for records management staff to manage records in an electronic environment was an impediment to the implementation of 
the National Archives and Records Management System (NARMS) in the then Ministry of Labour and Home Affairs in Botswana. Lack of capacity to manage electronic records is not limited to Botswana as it is also common across the ESARBICA region (Kemoni 2009; Mnjama \& Wamukoya 2007; Mosweu \& Kenosi 2018). This state of affairs also obtains in the rest of Africa such as in Ghana (Adu \& Ngulube 2017; Asogwa 2012). South Africa is no exception. Luthuli (2017) also identifies the lack of integration of ICT when it comes to the management of records including infrastructure in South African hospitals in KwaZulu Natal. The use of cloud computing can be useful to management of electronic records.

Security and privacy of records within electronic records management systems is important in that they must remain authentic and reliable in order to make decisions. Keakopa (2008) cautions that the authenticity and reliability of electronic records are often questioned because of possible changes to content or structure. Although the court records management system (CRMS) deployed in the Gaborone Magistrates Court in Botswana was a secure system, Mosweu and Kenosi (2018) discovered that officers shared passwords. This compromised the security of records in the system. The privacy of records in online databases can also be compromised if necessary caution is not exercised. The data about individuals held by government and private organisations threaten their privacy if they are not properly managed (Ojedokun 2008).

\section{Conclusion}

Cloud computing in the arena of archives and records management is indeed an Achilles heel of the digital area in the era of records and information management. The question is, can it be wished away? Certainly not. It is part of digital records management and the challenge is posed to records management professionals to coexist with it, managing it alongside managing records in the digital environment. Rogers (2017) avers that the work of archivists and records managers is disrupted by ubiquitous and rapidly changing technology of record creation, communication, distribution and storage, specifically the affordances of the Internet and cloud computing. These disruptions have altered the way the said records management professionals think about archives and records.

It is notable that using cloud-computing services for records management compete for funding with other areas of organisational management. Admittedly, it may be expensive to use the cloud to manage organisational records but the expenses involved can be offset by the benefits and opportunities brought by cloud computing. It is the duty of archives and records management professionals to convince those in authority through cost benefit analysis, that records management can benefit from cloud computing. It is only through the use of ICTs' cloud-computing services that Africa can become a player in the global economic scene, and participate in the knowledge economy. Records managers, as well as archivists need to keep up with times to be able to compete with the fast-changing world within the digital era. It is only through concerted efforts by archives and records management professionals, ICT vendors and experts, and archiving agencies that cloud computing in records management can cease to be an Achilles heel and become instead a sea of opportunities for Africa's economic development.

\section{Recommendations}

In view of the stated benefits and challenges of cloud computing, this article presents the following recommendation in the field of archives and records management in Africa:

- Training: In order for African countries to cope with cloud-computing services in the field of records management, one proposed solution to the skills problem has been better staff training programmes focused on technology and digital records (Keakopa 2002). In addition to build capacity, government should pay competitive salaries and even declare technical skills and competencies as scarce skills with an allowance meant to attract and retain skilled professionals. When assessing cloud readiness of selected African countries (Ethiopia, Ghana, Kenya, Nigeria and Tunisia), Gillwald and Moyo (2012:5), it was also observed that there is a need to build local and knowledge in high technology, including cloud computing, in Africa. Continuous education and training can also raise awareness of cloud-computing services and their impact on records management.

- Legislation: Studies by Ngoepe and Keakopa (2011), Mnjama (2014) and Ngoepe and Saurombe (2016) revealed that archival legislation in most African countries was not adequate for the controlling of records in an automated environment. It is thus recommended that archival legislation should be amended to cater for digital records management, including cloud computing. This also includes data protection legislation. In the case of Botswana, a data protection law was enacted in 2018 for purposes of regulating the collection and management of personal information (Government of Botswana 2018).

- Assessment of cloud services providers: It is recommended that prior to the adoption of cloudcomputing services, potential client organisations should assess cloud-computing services to determine whether they meet required records management functionalities. The Government of South Australia (2015) has a checklist which is used to assess cloud-computing service providers before engaging them to provide a cloudcomputing service. Capacity building to enable records managers to play this role is a necessity. InterPARES Trust (2016) has issued a Checklist for Cloud Service Contracts and these can be used as guidelines to inform decisions made by records managers.

- Insertion of a records management clause in cloud service contracts: Kentucky State Government (2012) advises agencies to maintain responsibility for 
managing records in the cloud. That is ensured by including a provision for records management in any contract or similar agreement with cloud service vendors. This helps to ensure that client organisations and even the vendors meet their statutory records management responsibilities. Just to cite a few, the clauses should include the issue of who owns the record, procedures for information preservation and disposition, maintenance of security, confidentiality and privacy, data location and cross-border flows, and whether there are procedures for preserving the usability, authenticity, reliability and integrity of records (InterPARES Trust 2016).

- Interoperability: Information deposited in the information systems should be available as long as needed for operational use. According to Kentucky State Government (2012), organisations should still have access to information if systems become obsolete and data are migrated to newer software applications. It is recommended that organisations in Africa should not use proprietary systems that require considerable amounts of money and effort to remove and transfer data to newer technologies. Allocate a certain department to manage cloud computing such as is done in the Philippines, where they use the Department of Information and Communications Technology.

\section{Acknowledgements}

\section{Competing interests}

The authors declare that they have no financial or personal relationships that may have inappropriately influenced them in writing this article.

\section{Authors' contributions}

The authors equally contributed to the writing of this article.

\section{Ethical consideration}

This article followed all ethical standards for carrying out research without direct contact with human or animal subjects.

\section{Funding information}

This research received no specific grant from any funding agency in the public, commercial or not-for-profit sectors.

\section{Data availability statement}

Data sharing is not applicable to this article as no new data were created or analysed in this study.

\section{Disclaimer}

The views and opinions expressed in this article are those of the authors and do not necessarily reflect the official policy or position of any affiliated agency of the authors.

\section{References}

Abubakar, A.D., Bass, J.M. \& Allison, I., 2014, 'Cloud computing: Adoption issues for sub-Saharan African SMEs', Electronic Journal of Information Systems in Developing Countries 62(1), 1-17. https://doi.org/10.1002/j.1681-4835.2014. tb00439.x

Adane, M., 2018, 'Cloud computing adoption: Strategies for sub-Saharan Africa SMEs for enhancing competitiveness', African Journal of Science, Technology, Innovation and Development 10(2), 197-207. https://doi.org/10.1080/20421338. 2018.1439288

Adu, K.K. \& Ngulube, P., 2017, 'Key threats and challenges to the preservation of digital records of public institutions in Ghana', Information, Communication \& Society 20(8), 1127-1145. https://doi.org/10.1080/1369118X.2016.1218527

ARMA International (ARMA), 2010, Making a jump to the cloud? How to manage information governance challenges, viewed 12 July 2017, from https://www. arma.org/docs/hot-topic/makingthejump.pdf.

Asogwa, B.E., 2012, 'The challenge of managing electronic records in developing countries: Implications for records managers in sub Saharan Africa', Records Management Journal 22(3), 198-211. https://doi.org/10.1108/09565691211 283156

Australian Capital Territory, 2008, Guideline for records management number 8 Business continuity and records management, viewed 06 February 2018, from https://www.territoryrecords.act.gov.au/_data/assets/pdf_file/0006/472704/ Guideline-No-8-Business-Continuity-August-2008.pdf.

Awokola, B.I., Abioye-Kuteyi, E.A., Otoru, O.O., Oyegbade, O.O., Awokola, E.O. Awokola, O.A. et al., 2012, 'Practical challenges of setting up an electronic medical record system in a Nigerian tertiary hospital: The Wesley guild hospital experience', Middle East Journal of Family Medicine 10(2), 37-42.

Bagula, A., Zennaro, M., Nungu, A. \& Nkoloma, M., 2011, 'Bridging the digital divide in Africa: A technology perspective', Wireless Communication and Information 7-27, viewed 13 October 2019, from http://wireless.ictp.it/Papers/WCI2011.pdf.

Bassett, C., 2015, 'Cloud computing and innovation: Its viability, benefits, challenges and records management capabilities', MA thesis, University of South Africa, Pretoria.

Blaisdell, R., 2012, How performance issues impact cloud adoption, viewed 13 October 2019, from https://rickscloud.com/how-performance-issues-impact-cloudadoption/.

Carroll, M., Van der Merwe, A. \& Kotzé, P., 2011, Secure cloud computing: Benefits, risks and controls, viewed 13 October 2019, from https://www.researchgate. net/publication/224259118_Secure_cloud_computing_Benefits_risks_and controls.

Charlesworth, A., Beagrie, N. \& Miller, P., 2014, How cloud storage can address the needs of public archives in the UK, viewed 12 October 2019, from https:// needs of public archives in the UK, vilewed 12 October 2019, from https:// address-the-need-of-public-archives-in-the-uk(33717cd8-25c1-4ce6-95bbe2cdced48142).html.

Cloud Security Alliance, 2012, Secaas implementation quidance: Business continuity and disaster recovery, viewed 05 February 2018, from https://downloads. cloudsecurityalliance.org/initiatives/secaas/Secaas_Cat 9_BCDR_Implementation Guidance.pdf.

Cloud Standards Customer Council, 2017, Cloud standards customer council announces version 3.0 of practical guide to cloud computing, viewed 23 January 2018, from https://www.businesswire.com/news/home/20171205005186/en/ Cloud-Standards-Customer-Council-Announces-Version-3.0.

Duranti, L., 2013, Records in the Cloud (RiC) user survey report, viewed 13 October 2019, from http://www.recordsinthecloud.org/assets/documents/RiC_Oct23 2013_User_Survey_Report.pdf.

Dvorak, J.C., 2011, The cloud: Risky, unreliable, and dumb, viewed 12 October 2018 from https://www.pcmag.com/article2/0,2817,2385463,00.asp.

Geier, C., 2010, Leveraging cloud storage with SharePoint and StoragePoint, viewed 10 November 2017, from https://www.metalogix.com/docs/default-source/ product-collateral/Leveraging_Cloud_Storage_With_SharePoint.pdf.

Gillwald, A. \& Moyo, M., 2012, The cloud over Africa, viewed 04 January 2018, from https://www.researchictafrica.net/publications/Evidence_for_ICT_Policy_ Action/Policy_Paper_20_-_The_cloud_over_Africa.pdf.

Government of Botswana, 2018, Data Protection Act, Government Printer, Gaborone.

Government of South Australia, 2015, Cloud computing and records management viewed 10 July 2017, from https://government.archives.sa.gov.au/sites/default/ files $/ 20150706 \% 20$ Cloud $\% 20$ Computing $\% 20$ and $\% 20$ Records $\% 20$ Management $\% 20$ Final\%20V1.pdf.

Haskew, J., Rø, G., Turner, K., Kimanga, D., Sirengo, M. \& Sharif, S., 2015 Implementation of a cloud-based electronic medical record to reduce gaps in the HIV treatment continuum in rural Kenya', PLoS One 10(8), e0135361. https://doi. org/10.1371/journal.pone.0135361

Hon, W.K., Hörnle, J. \& Millard, C., 2012, 'Data protection jurisdiction and cloud computing - When are cloud users and providers subject to EU data protection law?', The Cloud of Unknowing International Review of Law, Computers \& Technology 26(2), 129-164. https://doi.org/10.2139/ssrn.1924240

Hsu, W.L., 2012, 'Conceptual framework of cloud computing governance model An education perspective', IEEE Technology and Engineering Education 7(2), 12-16.

IBM, 2010, Integrated service management and cloud computing: More than just technology best friends, viewed 13 October 2019, from https://www.ibm.com/

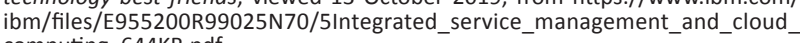
computing_644KB.pdf. 
International Records Management Trust (IRMT), 2004, Evidence-based governance in the electronic age, IRMT, London.

International Telecommunications Union (ITU), 2012, Cloud computing in Africa: Situation and perspectives, viewed 10 July 2019, from http://www.itu.int/ITU-D/ treg/publications/Cloud_Computing_Afrique-e.pdf.

InterPARES, 2014, Contract terms with cloud service providers, viewed 08 July 2017 from https://interparestrust.org/assets/public/dissemination/NA10_20140520 ContractTerms_NAWorkshop3 Report_Final.pdf.

InterPARES/ICA, 2012, Digital records pathways: Topics in digital preservation Module 8: Cloud Computing Primer, viewed 07 November 2018, from http:// www.interpares.org/\%5C/ip3/display_file.cfm?doc=ip3_canada_gs12 module_8_july-2012_DRAFT.pdf

InterPARES Trust (InterPARES), 2016, Checklist for cloud service contracts: Final version viewed 10 July 2019, from https://interparestrust.org/assets/public/dissemination/ NA14_20160226_CloudServiceProviderContracts_Checklist_Final.pdf.

InterPARES, 2018a, Investigating the management of digital records in enterprisewide systems: Botswana, viewed 13 October 2019, from https://interparestrust.
org/assets/public/dissemination/AF04_FinalReport_July2018.pdf.

InterPARES, 2018b, Implementation of enterprise wide systems to manage digital records in Kenya's public sector, viewed 13 October 2018, from https:// interparestrust.org/assets/public/dissemination/AF05FinalReportMarch2018.pdf.

InterPARES, 2018c, Enterprise digital records management in Zimbabwe, viewed 13 October 2019, from https://interparestrust.org/assets/public/dissemination/ AF03ZimbabweLitReviewJuly2018.pdf.

ITA, 2016, 2016 Top markets report cloud computing: A market assessment tool for U.S. exporters, viewed 13 October 2019, from https://www.trade.gov/ topmarkets/pdf/Cloud_Computing_Executive_Summary.pdf.

Kabata, V., 2012, 'Outsourcing records storage to the cloud: Challenges and prospects for African records managers and archivists', Mousaion 30(2), 137-157.

Kanyengo, C., 2009, 'Managing digital information resources in Africa: Preserving the integrity of scholarship', The International Information \& Library Review 41(1), 34-43. https://doi.org/10.1016/j.iilr.2008.08.003

Keakopa, S.M., 2002, 'Automated records management systems in the ESARBICA region', ESARBICA Journal 21, 41-48. https://doi.org/10.4314/esarjo.v21i1.30977

Keakopa, S.M., 2008, Trends in long-term preservation of digital information: Challenges and possible solutions for Africa, viewed 20 August 2018, from https:// www.codesria.org/IMG/pdf/12_Segomotso_M-_Keakopa-2.pdf.

Keakopa, S.M., 2010, 'Overview of archival and records management developments in the ESARBICA region', Archives and Manuscripts 38(1), 51-77.

Kemoni, H.N., 2009, 'Management of electronic records - Review of empirical studies from the Eastern, Southern Africa Regional Branch of the International Council on Archives (ESARBICA) region', Records Management Journal 19(3), 190-203. https://doi.org/10.1108/09565690910999184

Kentucky State Government, 2012, Cloud computing: Implications and guidelines for records management in Kentucky State Government, viewed 13 October 2019, from https://kdla.ky.gov/records/Documents/Cloud\%20Computing\%20Guidelines $\% 20$ Version\%201.pdf.

Lesame, N., 2005, New media. Technology and policy in developing countries, Van Schaik, Hatfield.

Lewis, G.A., 2012, The role of standards in cloud-computing interoperability, viewed 18 September 2018, from http://www.sei.cmu.edu.

Low, H.A., 2012, Primer on policy implications of cloud computing, viewed 10 July 2018, from http://ftp.maps.canada.ca/pub/nrcan_rncan/publications/ess_sst/ 291/291945/cgdi_ip_20e.pdf.

Luthuli, L.P., 2017, 'Medical records management practices in public and private hospitals in Umhlathuze Area, South Africa', Master's thesis, University of Zululand.

McClelland, R., Hackett, Y., Hurley, G. \& Collins, D., 2014, Agreements between cloud service providers and their clients: A review of contract terms, viewed 08 April 2018, from http://www.girona.cat/web/ica2014/ponents/textos/id210.pdf.

McKemmish, S., 2013, Recordkeeping and archiving in the cloud: Is there a silver lining? viewed 08 March 2018, from http://infoz.ffzg.hr/INFuture/2013/papers/1-02\%20 McKemmish,\%20Recordkeeping\%20and\%20Archiving\%20in\%20the \%20Cloud.pdf.

Mensah, S.O., 2019, Emerging technologies: Bridging the digital gap in Africa, viewed 11 June 2019, from https://www.internetsociety.org/blog/2019/01/emergingtechnologies-bridging-the-digital-gap-in-africa/.

Miniwatts Marketing Group, 2019, Internet users statistics for Africa, viewed 09 July 2019, from https://www.internetworldstats.com/stats1.htm.

Mnjama, N., 2014, 'Archival legislation and archival services in Africa', in P.M.M Sebina, K.H. Moahi \& K.J. Bwalya (eds.), Digital access and e-government: Perspectives from developing and emerging countries, pp. 27-47, IGI Global, Hershey PA.

Mnjama, N. \& Wamukoya, J., 2007, 'E-government and records management: An assessment tool for e-records readiness in government', The Electronic Library 25(3), 274-284. https://doi.org/10.1108/02640470710754797

Moatlhodi, T. \& Kalusopa, T., 2016, 'An assessment of e-records readiness at The Ministry of Labour and Home Affairs, Gaborone, Botswana', Mousaion 34(3), 1-22.

Mosweu, T.L., 2012, 'Assessment of the court records management system in the delivery of justice at the Gaborone Magisterial District', MA thesis, University of Botswana, Gaborone.

Mosweu, O., 2016, 'Critical success factors in electronic document and records management systems implementation at the Ministry of Trade and Industry in Botswana', ESARBICA Journal 35, 1-13.
Mosweu, T.L. \& Kenosi, L., 2018, 'Implementation of the court records management system in the delivery of justice at the Gaborone Magisterial District, Botswana', Records Management Journal 28(3), 234-251. https://doi.org/10.1108/RMJ-112017-0033

Mugyenyi, R., 2018, 'Adoption of cloud computing services for sustainable development of commercial banks in Uganda', Global Journal of Computer Science and Technology: B Cloud and Distributed 18(1), 1-10.

Mujinga, M. \& Chipangura, B., 2011, 'Cloud computing concerns in developing economies', paper published in the Proceedings of the 9th Australian Information Security Management Conference, Edith Cowan University, Perth, Western Australia, 5-7th December. https://doi.org/10.4225/75/57b5486bcd8c8

Mutula, S., 2008, 'Digital divide and economic development: Case study of subSaharan Africa', The Electronic Library 26(4), 468-489. https://doi.org/10.1108/ 02640470810893738

National Archives of Australia, 2018, Business continuity and disaster planning viewed 04 January 2019, from http://www.naa.gov.au/information-management/ managing-information-and-records/protecting/business-continuity/index.aspx.

National Institute of Standards and Technology (NIST), 2011, Guidelines on security and privacy in public cloud computing, viewed 10 December 2018, from http:// nvlpubs.nist.gov/nistpubs/Legacy/SP/nistspecialpublication800-144.pdf.

Ngoepe, M. \& Keakopa, S.M., 2011, 'An assessment of the state of national archival and records systems in the ESARBICA region', Records Management Journal 21(2), 145-160. https://doi.org/10.1108/09565691111152071

Ngoepe, M. \& Makhubela, S., 2015, 'Justice delayed is justice denied: Records management and the travesty of justice in South Africa', Records Management Journal 25(3), 288-305. https://doi.org/10.1108/RMJ-06-2015-0023

Ngoepe, M. \& Saurombe, A., 2016, 'Provisions for managing and preserving records created in networked environments in the archival legislative frameworks of selected member states of the Southern African development community' selected member states of the Southern African development community,
Archives and Manuscripts 44(1), 24-41. https://doi.org/10.1080/01576895.2015. 1136225

Ngulube, P., 2004, 'Fostering accountability: Opportunities and challenges faced by records managers in changing societies', ESARBICA Journal 23, 23-32. https://doi. org/10.4314/esarjo.v23i1.30961

Nwabuonu, O.G. \& Nwachukwu, N.G., 2014, Cloud computing: A key to IT development in West African sub region, viewed 10 January 2019, from http://www.iosrjournals. org/iosr-jce/papers/Vol16-issue2/Version-10/Q0162109498.pdf.

Odekunle, F.F., Odenkunle, R.O. \& Shankar, S., 2017, 'Why sub-Saharan Africa lags in electronic health record adoption and possible strategies to increase its adoption in this region', International Journal of Health Sciences 11(4), 59-64.

Ojedokun, A., 2008, 'Towards developing Africa's web content: Challenges, strategies and tools', in L.O. Aina, S.M. Mutula \& M.A. Tiamiyu (eds.), Information and knowledge management in the digital age: Concepts, technologies and African perspectives, pp. 70-98, Third World Information Services Limited, Ibadan.

Oyeleye, C.A., Fagbola, T.M. \& Daramola, C.Y., 2014, 'The impact and challenges of cloud computing adoption on public universities in Southwestern Nigeria', International Journal of Advanced Computer Science and Applications 5(8), 13-19.

Palmer, G., 2012, Keeping tax records in the cloud, viewed 13 October 2019, from https://www.fanews.co.za/article/legal-affairs/10/general/1120/keeping-taxrecords-in-the-cloud/12888.

Rajesh, S., Swapna, S. \& Reddy, P.S., 2012, 'Data as a service (Daas) in cloud computing [Data-As-A-Service in the age of data', Global Journal of Computer Science and Technology Cloud \& Distributed 12(11), 1-6.

ResearchICTafrica.net, 2017, Drivers and barriers for cloud computing adoption in the public sector in Kenya, viewed 10 June 2019, from https://researchictafrica.net/ ria rap/2017/11/22/drivers-and-barriers-for-cloud-computing-adoption-in-thepublic-sector-in-kenya/.

Rogers, C., 2017, SASA keynote address, viewed 13 October 2019, from http://www. saarchivist.co.za/past-events/past-sasa-events/2017-conference/2017-presaarchivist.co.za/past-events/past-sasa-events/20
conference-workshop/21-rogers-sasa-keynote/file.

Sabi, H., 2014, Opportunities and challenges for adopting cloud computing at universities in developing countries, viewed 13 October 2019, from https://www.
researchgate.net/publication/273951114_OPPORTUNITIES AND CHALLENGES FOR ADOPTING_CLOUD_COMPUTING_AT_UNIVERSITIES_IN_DEVELOPING FOR_ADOPTIN
COUNTRIES.

Seifu, S.D., Dahiru, A.A., Bass, J.M. \& Allison, I.K., 2017, 'Cloud-computing: Adoption issues for Ethiopian public and private enterprises', The Electronic Journal of Information Systems in Developing Countries 78(7), 1-14.

Solicitors Regulation Authority, 2013, Silver linings: Cloud computing, law firms and risk, viewed 13 October 2019, from https://www.legaltechnology.com/wpcontent/uploads/2014/10/cloud-computing-law-firms-risk.pdf.

Somepalle, S., 2015, 3 service and 4 deployment models of cloud computing, viewed 06 May 2018, from https://www.linkedin.com/pulse/3-service-4-deploymentmodels-cloud-computing-sankar-somepalle.

Spectar, J.M., 2000, 'Bridging the global digital divide: Frameworks for access and the World Wireless Web', North Carolina Journal of International Law and Commercia Regulation 26(1), 57-103.

State of Kentucky, 2012, Cloud computing: Implications and guidelines for records management in Kentucky State Government, viewed 04 October 2018, from http://kdla.ky.gov/records/Documents/Cloud\%20Computing\%20Guidelines\%20 Version\%201.pdf.

Thomas, P.Y. 2009, Cloud Computing: A potential paradigm for practicing the scholarship of teaching and learning, viewed 01 November 2019, from https:// pdfs.semanticscholar.org/4ed7/350c2d9c15f2b5772f68b2d5f3f20fba77cf.pdf 
Venkatramam, A., 2012, Lack of cloud standards and interoperability hinders cloud adoption, viewed 12 September 2017, from http://www.computerweekly.com/ news/2240160652/Lack-of-cloud-standards-and-interoperability-hinders-cloudadoption.

Wamukoya, J. \& Mutula, S., 2005, 'E-records management and governance in east and southern Africa', Malaysian Journal of Library \& Information Science 10(2), 67-83.

Wamuyu, P.K., 2017, 'Use of cloud computing services in micro and small enterprises: A fit perspective', International Journal of Information Systems and Project Management 5(2), 59-81.
Wang, W.Y., Rashid, A. \& Chuang, H.M., 2011, 'Toward the trend of cloud computing', Journal of Electronic Commerce Research 12(4), 238-242.

Winkler, V.J.R., 2012, Cloud computing: Legal and regulatory issues, viewed 05 July 2017, from https://technet.microsoft.com/en-us/library/hh994647.aspx.

Yimam, D. \& Fernandez, E.B., 2016, 'A survey of compliance issues in cloud computing' Journal of Internet Services and Applications 7(5), 1-12. https://doi.org/10.1186/ s13174-016-0046-8

Zissis, D. \& Lekkas, D., 2012, 'Addressing cloud computing security issues', Future Generation Computer Systems 28(1), 583-592. https://doi.org/10.1016/j.future. 2010.12.006 